\title{
A Review of the Associations between Dietary Fiber Intake and Cancer Prevention or Prognosis
}

\author{
Ying Xie, Yu Wei Ren, Xiao Ling Li, Zeng Ning Li \\ Department of Clinical Nutrition, The First Hospital of Hebei Medical University, Shijiazhuang 050031, Hebei, China
}

\begin{abstract}
The increase in tumor incidence is closely related to dietary factors. In recent years, many researchers have carried out in-depth research to investigate whether increasing the intake of dietary fiber can prevent tumors and improve the prognosis, but the results have been unclear. We herein searched the literature in common academic databases and incorporated and summarized the relevant articles. The literature clearly indicates that dietary fiber can protect against the following cancers: colorectal cancer, breast cancer, pancreatic cancer, ovarian cancer, and head and neck cancer. There is also evidence that dietary fiber intake can exert protective effects against cancers of the liver, lung, stomach, small bowel, kidney, and esophagus, as well as lymphoma, but the data have so far been relatively limited. The effects on endometrial cancer and prostate cancer still remain uncertain. In terms of the effects on the cancer prognosis, dietary fiber does not appear to have an impact on colorectal cancer or breast cancer. Although more research is needed for some kinds of cancer, it is clear that increasing the intake of dietary fiber is beneficial for preventing the occurrence and development of several major types of cancer, with no major adverse effects. We therefore recommend that most of individuals increase their intake of dietary fiber.
\end{abstract}

Key words: Dietary fiber; Cancer; Soluble dietary fiber; Insoluble dietary fiber

\section{Introduction}

With the development of better screening and diagnostic approaches and more effective treatments, cancer has become a chronic disease [1]. Due to the changes in lifestyle, the environment and dietary structure, the cancer burden (the number of new cancer cases or deaths) has shown an upward trend in recent years. Fifteen million new cancer cases and 12 million deaths were predicted in 2020 [2]. Colorectal cancer is the third most common cancer type and the fourth leading cause of cancer death in the world, with an estimated 1.4 million new cases and nearly 700,000 deaths in 2012. It increased to 1.8 million new cases and nearly 900,000 deaths in 2018 [3]. The global burden of colorectal cancer is expected to increase by $60 \%$ in 2030 , meaning that there will be approximately 2.2 million new cases and 1.1 million deaths that year unless significant changes are made to prevention or treatment [4]. According to previous epidemiological studies, alcohol and red meat consumption increase the risk of colorectal cancer [5].

In addition, there are about 330,000 pancreatic cancer deaths worldwide each year, accounting for about $4 \%$ of all cancer cases [6]. Epidemiological studies suggest that dietary imbalances are a major cause of pancreatic cancer, while dietary risk factors mainly include high intake of red and processed meat and a lack of vegetables, fruits and dietary fiber [7-9]. Breast cancer is the most common

Corresponding author: Zeng Ning Li, MD, PhD, Department of Clinical Nutrition, The First Hospital of Hebei Medical University, 89 Donggang Road, Shijiazhuang 050031, Hebei, China. Tel:+86 311 8591 7290, 1863388 9888; Email: lizengning@126.com. malignant tumor in women. About 1.7 million people worldwide were diagnosed in 2012 [10]. The occurrence of breast cancer is also considered to be related to an unhealthy lifestyle, and effective prevention is essential to reduce the incidence of invasive breast cancer. Ovarian cancer is the second most common malignant tumor in the female reproductive system. Identifying modifiable risk factors is expected to reduce the occurrence of ovarian cancer. According to reports from developed countries, the incidence of endometrial cancer is on the rise and surpasses cervical cancer, making it the most common cancer in the female reproductive system. Of note, dietary factors are associated with endometrial cancer, and can interact with other factors (i.e., endocrine disruptors), and have an important influence on the incidence and outcome of the disease [11-13].

The World Health Organization analyzed numerous factors affecting human health, and showed that dietary factors appear to be among the most important factors, followed by genetic factors (15\%)[14]. The role of dietary fiber in the prevention and treatment of cancer has been the most studied topic, with studies mainly focused on colorectal cancer, breast cancer, ovarian cancer, liver cancer, endometrial cancer, prostate cancer, and esophageal cancer.

Dietary fiber is found in a wide range of human foods, mainly in cereals, potatoes, beans, vegetables, fruits and plant-based foods. More mature plants have a higher fiber content, and the fiber content is an important determinant of the tenderness of grains, with more tender grains have a lower fiber content. Dietary fiber can be divided into soluble dietary fiber (SDF) and insoluble dietary fiber (IDF) based on whether it is soluble in water. The former category includes inulin, pectin, fructooligosaccharide, and 
konjac. Major members of the IDF group include cellulose, lignin and methyl cellulose. Dietary fiber can improve the gut microbial state by selectively stimulating the growth or activity of one or more bacteria in the intestine, and are called probiotics. Due to its unique biological characteristics, dietary fiber can help to prevent tumors, as described below.

\section{Prevention of Cancer by Dietary Fiber Colorectal cancer}

Studies about the preventive role of dietary fiber against colorectal cancer have suggested that it affects the composition and metabolism of intestinal microbes, particularly the amount of butyric acid and deoxycholic acid in the colon, reducing the risk of colorectal cancer [15]. However, there was no statistically significant relationship between dietary fiber intake and colon cancer risk in different tumor subsites [16]. An analysis of dietary fiber types showed that increasing the fiber intake by $10 \mathrm{~g} /$ $\mathrm{d}$ reduced the risk of colorectal cancer by $9 \%$ for cereals; $16 \%$ for vegetable fiber and $22 \%$ for every $10 \mathrm{~g}$ increase in consumption of fruit fiber per day [17]. A large body of studies indicate that dietary fiber "safeguards" the colon and rectum against cancers. As shown in Table 1, numerous studies have demonstrated that grain, fruit and vegetablebased fiber consumption can all have protective effects against colorectal cancer [18-23]. However, other studies indicated that dietary fiber is not associated with a reduction in the colorectal cancer risk, with a few even finding a positive correlation between fiber consumption and cancer. Because all of these foods also contain other bioavailable ingredients, such as $\beta$-carotene and lycopene, the different levels in different foods may affect the results. In addition, the combination of these nutrients may have synergistic

Table 1 Meta-analyses of the correlation between dietary fiber and colorectal cancer.

\begin{tabular}{|c|c|c|c|c|}
\hline $\begin{array}{l}\text { Item } \\
\text { referenced }\end{array}$ & Ma Y et al. [16] & Oh H et al. [17] & Masrul M et al. [18] & $\begin{array}{l}\text { Gianfredi V et al. } \\
\text { [19] }\end{array}$ \\
\hline Study design & $\begin{array}{l}\text { Meta-analysis } \\
\text { (11 cohorts) }\end{array}$ & Meta-analysis (10 perspective studies) & $\begin{array}{l}\text { Meta-analysis ( } 8 \\
\text { case-control, } 2 \\
\text { cohort) }\end{array}$ & $\begin{array}{l}\text { Meta-analysis } \\
\text { ( } 7 \text { case-control, } 18 \\
\text { cohort) }\end{array}$ \\
\hline $\begin{array}{l}\text { Investigation } \\
\text { method }\end{array}$ & $\begin{array}{l}\text { Food-Frequency } \\
\text { questionnaire }\end{array}$ & Food-frequency questionnaire & $\begin{array}{l}\text { Food-frequency } \\
\text { questionnaire, } \\
\text { Prosky-AOCA }\end{array}$ & $\begin{array}{l}\text { Food-frequency } \\
\text { questionnaire, dietary } \\
\text { questionnaire, 7-day } \\
\text { recipe }\end{array}$ \\
\hline Disease & Colorectal cancer & Colorectal cancer, colorectal adenomas & Colorectal cancer & Colon cancer \\
\hline $\begin{array}{l}\text { The source } \\
\text { of dietary } \\
\text { fiber }\end{array}$ & $\begin{array}{l}\text { Dietary fiber, cereal } \\
\text { fiber, whole grain } \\
\text { products }\end{array}$ & Fruits, grains, vegetables, cereals, legumes & $\begin{array}{l}\text { Fruits, vegetables, } \\
\text { grains }\end{array}$ & Dietary fiber \\
\hline $\begin{array}{l}\text { Number of } \\
\text { subjects }\end{array}$ & 9,618 & $\begin{array}{l}12,771 \text { ( } 8,248 \text { colorectal cancer, } 4,523 \text { colorectal } \\
\text { adenomas) }\end{array}$ & 49,964 & 20,961 \\
\hline $\begin{array}{l}\text { Population/ } \\
\text { age }\end{array}$ & $\begin{array}{l}\text { American, European; } \\
\geq 35 \mathrm{y}\end{array}$ & European, American; $\geq 25 y$ & Asian; 18 85y & $\begin{array}{l}\text { Japanese, Chinese, } \\
\text { American, European, } \\
\text { Canadian; 20 93y }\end{array}$ \\
\hline Results & $\begin{array}{l}\text { The summary RR } \\
\text { of proximal colon } \\
\text { cancer and distal } \\
\text { colon cancer for } \\
\text { individuals with } \\
\text { the highest dietary } \\
\text { fiber intake relative } \\
\text { to those with the } \\
\text { lowest intake was } \\
0.86 \text { (95\% CI: } \\
0.78 \sim 0.95 \text { ) and } 0.79 \\
\text { (95\% CI: } 0.71 \sim 0.87) \text {, } \\
\text { respectively. }\end{array}$ & $\begin{array}{l}\text { The summary } \\
\text { RRs of colorectal cancer associated with each } 10 \\
\text { g/d increase in fiber intake were as follow: } \\
\left.\text { Cereal fiber: } 0.91 \text { ( } 95 \% \text { CI: } 0.82 \sim 1.00 ; I^{2}=0 \%\right) \text {; } \\
\text { Vegetable fiber: } 0.95 \text { (95\% CI: } 0.87 \sim 1.03, I^{2}= \\
0 \%) \text {; } \\
\text { Fruit fiber: } 0.91 \\
\left.\text { (95\% CI: } 0.78 \sim 1.06, I^{2}=0 \%\right) \text {; } \\
\text { Legume fiber: } 0.84\left(95 \% \text { CI: } 0.63 \sim 1.13, I^{2}=\right. \\
45 \%) \text {; } \\
\text { All fiber sources were inversely associated with } \\
\text { incident adenoma (Per } 10 \mathrm{~g} / \mathrm{d} \text { increase: RR [ } 95 \% \\
\text { CI]): } \\
\text { Cereals: } 0.81 \text { [0.54 1.21]; } \\
\text { Vegetables: } 0.84 \text { [0.71 0.98]; } \\
\text { Fruits: } 0.78 \text { [0.65 0.93]. }\end{array}$ & $\begin{array}{l}\text { High dietary fiber } \\
\text { intake prevents } \\
\text { colorectal cancer. } \\
\text { OR }=0.66(95 \% \mathrm{CI} \text { : } \\
0.56 \sim 0.77, P=0.008)\end{array}$ & $\begin{array}{l}\text { Dietary fiber intake } \\
\text { protects against colon } \\
\text { cancer risk. } \\
\mathrm{ES}=0.74(95 \% \mathrm{CI} \text { : } \\
0.67 \sim 0.82, P=0 \\
.000)\end{array}$ \\
\hline
\end{tabular}


effects [24-25].

\section{Pancreatic cancer}

The risk of pancreatic cancer is inversely associated with dietary fiber intake, and it was observed that increasing the daily intake by $10 \mathrm{~g}$ reduced the risk by 0.88 . Even though some studies have shown that dietary fiber does not reduce the risk of pancreatic cancer, it is thought to be beneficial for decreasing the damage caused by heavy intake of red and processed meat [26-28]. Some relevant studies are detailed as follows.

We included two meta-analyses and two case-control studies. The summary OR of pancreatic cancer associated with whole grain fiber intake was 0.76 (95\% CI: 0.64 0.91; $P=0.002$ ) in Lei QC et al. study [27]. And in Mao QQ et al. study showed there was a significant inverse relationship between high fiber intake and pancreatic cancer risk (OR $=0.52,95 \%$ CI: $0.44 \sim 0.61$ ) [28]. In other studies, some selected types of fiber and total fiber are inversely related to pancreatic cancer. Total fiber intake was inversely related to the risk of pancreatic cancer $(\mathrm{OR}=0.4,95 \% \mathrm{CI}$ : $0.2 \sim 0.7)$. An inverse association emerged between pancreatic cancer and both soluble $(\mathrm{OR}=0.4 ; 95 \% \mathrm{CI}: 0.2 \sim 0.7)$ and total insoluble fiber $(\mathrm{OR}=0.5 ; 95 \% \mathrm{CI}$ : $0.3 \sim 0.8)$. Fruit fiber intake was inversely associated with pancreatic cancer $(\mathrm{OR}=0.5 ; 95 \% \mathrm{CI}: 0.3 \sim 0.8)$, whereas grain fiber was not. People who consumed 2 servings of whole grains daily had a lower risk of pancreatic cancer than people who consumed $<1$ serving/d $(\mathrm{OR}=0.6,95 \% \mathrm{CI}$ : 0.31 1.2).Consuming more whole-grain or high-fiber foods may reduce the risk of pancreatic cancer [29-30]. Therefore, dietary fiber has a protective effect on pancreatic cancer.

\section{Cancers in women \\ Breast cancer}

Most studies have shown that dietary fiber can reduce the risk of breast cancer, and that fiber intake is inversely associated with the risk of breast cancer [31-33]. This is especially true for soluble dietary fiber from cereals, fruits and vegetables when compared to dietary fibers from alternative sources [10]. For every $10 \mathrm{~g} / \mathrm{d}$ increase in dietary fiber intake per day, the risk was significantly reduced by $7 \%$, which provides evidence that regular consumption of dietary fiber, plant fat, plant protein, and nuts during adolescence can help to reduce the cancer risk [10,3442]. However, in a prospective study of Chinese women published by Wen W, et al., dietary fiber intake was not associated with the risk of breast cancer [43].

\section{Endometrial carcinoma}

The results of epidemiological studies about the relationship between dietary fiber intake and endometrial cancer risk remain inconclusive. Three related metaanalyses have been performed. On the basis of 7 casecontrol studies, the random-effects summary risk estimate was $0.82(95 \%$ CI: $0.75,0.90)$ per $5 \mathrm{~g} / 1000$ kcal dietary fiber. The random-effects summary estimate was $0.71(95 \%$ CI: $0.59,0.85)$ for the comparison of the highest with the lowest dietary fiber intake in 8 case-control studies [44]. A significant negative association was observed between total dietary fiber intake and endometrial cancer risk in 11 casecontrol studies (OR $=0.76,95 \%$ CI: 0.64 0.89) [45]. But no association was found in the cohort study, even positive correlations of higher total fiber and cereal fiber intake with endometrial cancer risk [44-45]. Li HJ et al. [46] found a significant association between dietary fiber intake and endometrial carcinoma $(\mathrm{RR}=0.86,95 \% \mathrm{CI}: 0.78,0.93)$ .The findings revealed that the consumption of dietary fiber was associated with a $14 \%$ reduction in endometrial carcinoma risk. They showed a clear protective role of dietary fiber.

\section{Ovarian cancer}

Epidemiological studies have shown that dietary factors play an important role in the etiology of ovarian cancer, including dietary glucose loading [47], fat [48], phytoestrogens [49], vegetables and fruits [50]. Vegetables, fruits and grains are the main sources of dietary fiber, and the previous studies of the correlation between dietary fiber and ovarian cancer are shown. We included three metaanalyses. In Zheng B et al. study including 10 case-control and 3 cohorts, showed that the pooled multivariable RRs of ovarian cancer for the highest vs. the lowest category of dietary fiber intake was 0.78 (95\% CI: 0.70, 0.88). A doseresponse analysis showed a significant inverse association between dietary fiber intake and ovarian cancer risk (for an increase of $10 \mathrm{~g} / \mathrm{d}$; combined RR: 0.88 ; 95\% CI: 0.82 , $0.93)$. The risk of ovarian cancer was reduced by $22 \%$ in the group with the highest dietary fiber intake compared with the lowest. Furthermore, a $12 \%$ reduction in risk of ovarian cancer was found for per $10 \mathrm{~g}$ increase per day [51]. Xu H et al. meta include 14 case-control and 5 cohorts showed that the summary RR of the association between dietary fiber intake and ovarian cancer risk was 0.70 (95\% CI: $\left.0.57 \sim 0.87 ; I^{2}=83.5 \%, P<0.001\right)$. A dose-response analysis suggested that ovarian cancer risk decreased by $3 \%(\mathrm{RR}=$ 0.97, 95\% CI: $0.95 \sim 0.99$ ) for each $5 \mathrm{~g} / \mathrm{d}$ increase in dietary fiber intake [52]. Huang $\mathrm{X}$ et al. analysis of the primary pooled statistics revealed that the highest category of dietary fiber intake was associated with a significantly reduced risk of ovarian cancer compared with the lowest category (RR $=0.76 ; 95 \%$ CI: 0.702 0.823; $P<0.001)$. The association between dietary fiber intake and ovarian cancer risk was significant in both case-control studies and cohort studies [RR (95\% CI): 0.753 (0.682 0.832), 0.763 (0.633 0.920)] [53]. There is a protective role in preventing cancer.

According to the above contents, dietary fiber plays a positive role in the prevention of malignant cancers (such as breast cancer, endometrial cancer and ovarian cancer) in women. 


\section{Other malignancies}

In addition to the above, there have been studies of the potential preventive effects of dietary fiber on several other cancers, including head and neck cancer, prostate cancer, liver cancer, upper gastrointestinal cancer, gastric cancer, esophageal cancer, renal cancer, and lymphoma.

The studies of head and neck cancers included cancers of the oral cavity cancer, rhinocarcinoma, pharyngeal carcinoma, and salivary adenocarcinoma. The majority of cohort studies have shown that dietary fiber intake is inversely associated with the risk of head and neck cancer, with higher cereal fiber intake reducing the by about $48 \%$ [54-59]. A similar relationship was shown for the prostate cancer risk in cohort studies and meta-analyses, with especially potent effects for insoluble dietary fiber and legume fiber [60-62]. However, Suzukin R [63] and Wang $\mathrm{RJ}$ et al.[64] showed that dietary fiber was not associated with prostate cancer.

Dietary fiber does appear to play a protective role for liver and kidney cancer, especially grain fiber intake. However, the results for bran fiber intake were unclear [6567]. In a pooled analysis of lung cancer, dietary fiber and yogurt consumption synergistically reduced the risk of lung cancer [68]. In studies of upper gastrointestinal cancer, gastric cancer, esophageal cancer, and small bowel cancer, dietary fiber was considered to be inversely associated with tumor risk, and an increase in fiber intake by $10 \mathrm{~g} / \mathrm{d}$ reduced the risk of gastric cancer by $44 \%$, and reduced the risk of esophageal cancer by $31 \%$. Individuals with the highest intake of whole grains and yellow/orange vegetables had risk factors of 0.53 and 0.58 , respectively, compared to those with the lowest intake with regard to the development of upper gastrointestinal cancer [69-73]. The intake of vegetable and fruit fibers, especially green leafy vegetables and cruciferous vegetable fibers, was found to be linked to a reduced risk of non-Hodgkin's lymphoma [74-75].

\section{Prognostic Impact of Dietary Fiber}

The literature about the prognostic impact of dietary fiber on various cancers is limited. A few studies reported an inverse relationship between dietary fiber intake and the recurrence and death from colorectal adenoma. However, most studies have shown that dietary fiber is not linked to the prognosis of colorectal cancer. In a four-year supplementary dietary fiber intervention study, participants receiving dietary fiber had a higher risk of experiencing intestinal cancer than the control group, with an absolute increase in risk of $1 \%$ [9,76-83]. Similarly, dietary fiber did not reduce the recurrence rate or mortality of breast cancer, even though there appeared to be a trend for fiber to decrease the incidence of the disease. However, these data were not statistically significant [84-85]. Henson $\mathrm{CC}$ et al. analyzed the gastrointestinal toxicity in adults receiving pelvic radiotherapy after nutritional intervention, and showed that adjusting the dietary fiber intake had no appreciable effect on diarrhea caused by radiotherapy [86].

\section{Mechanisms Underlying the Anticancer Effects of Dietary Fiber}

The main mechanisms underlying the anticancer effects of dietary fiber include [87], as shown in Figure 1: (1) The strong hydrophilicity of dietary fiber can promote higher fecal volume and weight, which enhances intestinal peristalsis and facilitates fecal excretion. In this way, it can dilute the concentration of carcinogens and shorten their retention time in the intestine [8]; (2) SDF can be degraded by bacteria to form short-chain fatty acids (SCFA) in the colon. SCFA promote the growth of beneficial bacteria, and inhibit the growth and reproduction of spoilage bacteria. Promoting this change in bacterial colonization is beneficial

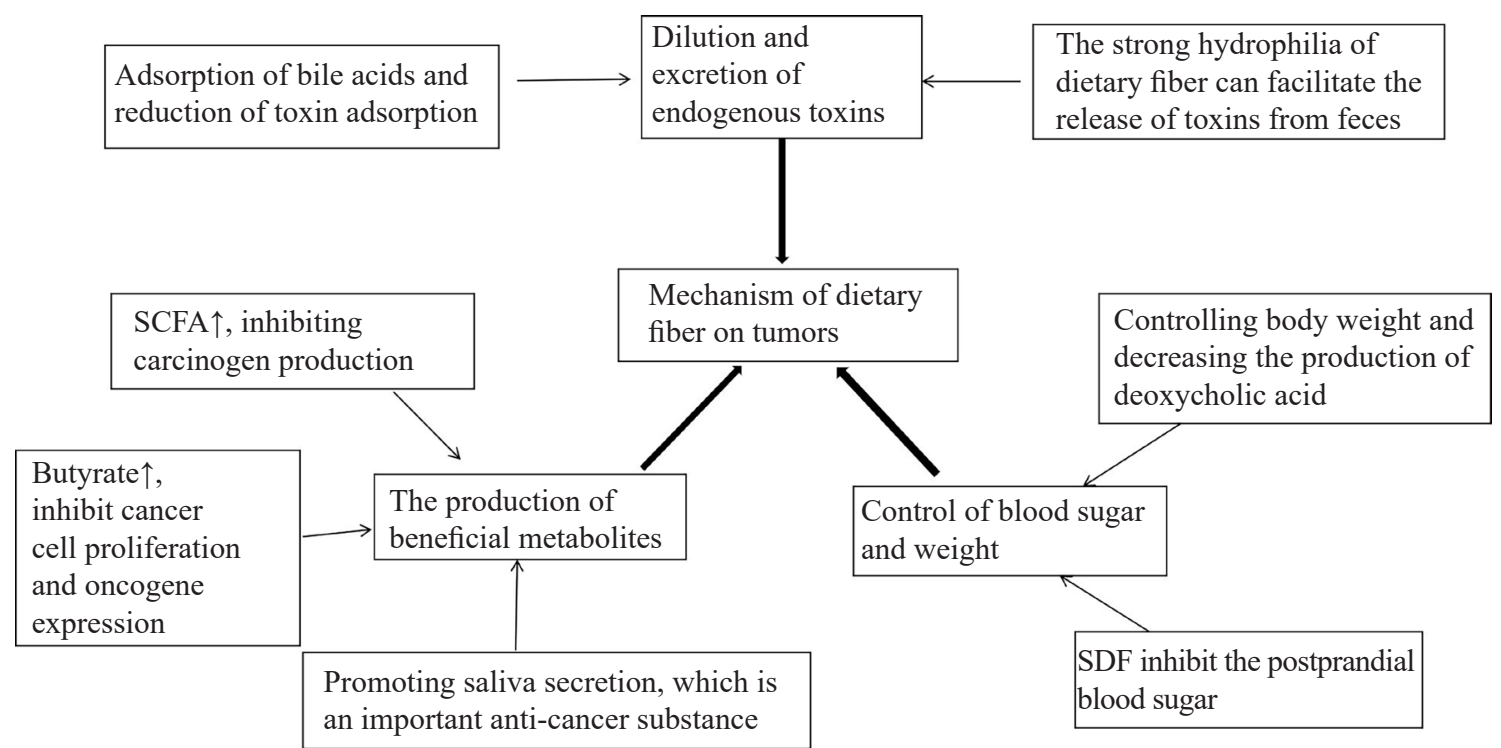

Figure 1 Mechanism of dietary fiber on tumors. SCFA: Short-chain fatty acids; SDF: Soluble dietary fiber. 
to the normal intestinal barrier, thereby inhibiting carcinogen production and promoting the decomposition of carcinogens [88]; (3) Dietary fiber is the main substrate of intestinal bacterial fermentation, which produces a series of beneficial metabolites, especially butyrate [89], which can inhibit the growth of bacteria, nourish colon wall cells, inhibit tumor cell proliferation, inhibit cell transformation, inhibit oncogene expression, and improve lipid metabolism [87,90]; (4) Dietary fiber can increase satiety and limit energy intake, it also promotes lipid oxidative metabolism and inhibits fat storage, thereby helping control body weight. It can also increase the production of deoxycholic acid and hepatic intestinal circulation, which can help reduce the occurrence of liver cancer [91]; (5) The absorption of cholesterol, fatty acids and endogenous toxins can be reduced by the increased adsorption to bile acids [92,93]; (6) SDF can delay and inhibit the digestion of sugar and improve the insulin sensitivity of peripheral tissues, so the postprandial blood glucose level can be reduced [90]; (7) By strengthening mastication to promote saliva secretion, which may also lead to anti-cancer effects [87].

\section{Conclusion}

Dietary factors can alter the risk of various cancers. High dietary fiber intake plays a role in preventing multiple cancers. In addition to preventive effects, adjusting a patient's diet is also important for improving the response to cancer treatment. Our findings are consistent with previous reports. A systematic review published by Makarem $\mathrm{N}$ et al. [59] showed that whole grain fiber plays a protective role in head and neck cancer, renal cancer, and gastrointestinal cancer. The view that dietary fiber reduces the risk of gastrointestinal cancer, breast cancer, pancreatic cancer, ovarian cancer, head and neck cancer is relatively explicit, but there is a lack of research support with regard to the impact on other cancers.

The previously-published studies show that different sources of dietary fiber play different roles in the risk of cancer, even for the same tumor type. For example, whole grain and bran have potential preventive effects against liver cancer, but no such role has been found for fiber from other sources. Similarly, the source of dietary fiber found to have the most beneficial effects is not consistent in the studies of endometrial cancer, breast cancer and so on. Consequently, determining the specific type, dose, and timing of dietary fiber intake is key to explore the effects on tumor growth and development. In terms of the prognosis, most studies have not found any significant positive effect, but further studies are needed due to the relative lack of data.

Patients who have inadequate dietary fiber intake are at an increased risk for several types cancer. However, while extensive dietary fiber intake promotes the excretion of toxic and harmful substances, it also can remove some essential nutrients and lead to symptoms such as malnutrition, intestinal flatulence, indigestion, and diarrhea.
Thus, while the intake of an adequate amount of fiber is beneficial, the increase in fiber intake should be moderate to avoid potential adverse effects.

Much effort has been invested in deciding on the recommended dietary fiber intake. The Food and Agriculture Organization of the United Nations recommends that healthy individuals should consume $27 \mathrm{~g} / \mathrm{d}$. The German Society for Nutrition recommends at least $30 \mathrm{~g} / \mathrm{d}$, with a recommended ratio of IDF to SDF of $2: 1$. British dietitians recommend that individuals should consume $25 \sim 30 \mathrm{~g} / \mathrm{d}$. The U.S. Food and Drug Administration similarly recommends 25 30 g/d. The Chinese Nutrition Society recommends that healthy individuals should consume $30 \mathrm{~g} / \mathrm{d}$, with an additional 10 15 g/d [94] recommended for some groups (those with diabetes, cardiovascular and cerebrovascular diseases).

Dietary fiber can significantly protect against the following cancers: colorectal cancer, breast cancer, pancreatic cancer, ovarian cancer, head and neck cancer. Increasing dietary fiber intake by $10 \mathrm{~g} / \mathrm{d}$ can reduce the risk of colorectal cancer, pancreatic cancer, breast cancer, ovarian cancer, gastric cancer, and esophageal cancer. The effects of fiber intake on cancers of the liver, lung, stomach, small bowel, kidney, and lymphoma appear to be beneficial, but further studies are needed. The protective effect of dietary fiber on endometrial cancer and prostate cancer are also still being debated. In terms of cancer prognosis, dietary fiber does not seem to be associated with recurrent colorectal cancer or breast cancer. Thus, we consider that increasing the amount of dietary fiber intake is beneficial for preventing the occurrence and development of several major types of tumors, such as colorectal cancer, pancreatic cancer, breast cancer, ovarian cancer, gastric cancer, esophageal cancer, but this needs to be a lifelong dietary habit in order to achieve benefits. A short-term increase in consumption does not appear to have a significant impact, nor does consumption after a specific cancer type has already been diagnosed.

\section{Acknowledgements}

We thank all of the members of the study institutions for their help.

\section{Conflict of Interest}

The authors declare no conflict of interest.

\section{Funding}

This research was supported by The Key and Special Research Program of Health and Biologimedical of Heibei Province (No. 182777127D).

\section{References}

1. Bray F, Ren JS, Masuyer E, Ferlay J. Global estimates of cancer prevalence for 27 sites in the adult population in 2008. Int J Cancer 2013;132(5):1133-45. 
2. Bray F, Møller B. Predicting the future burden of cancer. Nat. Rev. Cancer2006;6(1):63-74.

3. Shelley MG. World Health Organization, International Agency for Research on Cancer, WHO Press, Advances in Nutrition. 2015.

4. Arnold M, Sierra MS, Laversanne M, Soerjomataram I, Jemal A, Bray F. Global patterns and trends in colorectal cancer incidence and mortality. Gut BMJ 2017;66(4):683-91.

5. Yunlin W, Xiaojun Y. The influence of dietary structure on colorectal neoplasms and its enlightenment to Chinese people's dietary structure. Theory and practice of diagnostics 2019;18(4):383-5.

6. Ferlay J, Soerjomataram I, Dikshit R, Eser S, Mathers C, Rebelo M, Parkin DM , Forman D, Bray F. Cancer incidence and mortality worldwide: Sources, methods and major patterns in GLOBOCAN 2012. Int J Cancer2015;136(5):359-86.

7. Kushi LH, Doyle C, McCullough M, Rock CL, Demark-Wahnefried W, Bandera EV, Gapstur S, Patel AV, Andrews K; Gansler T. American Cancer Society guidelines on nutrition and physical activity for cancer prevention. CA: CA Cancer J Clin 2012;62(1):30-67.

8. Larsson SC, Wolk A. Red and processed meat consumption and risk of pancreatic cancer: meta-analysis of prospective studies. Br J Cancer 2012;106(3):603-7.

9. Bidoli E, Pelucchi C, Zucchetto A, Negri E, Maso LD, Polesel J, Boz G, Montella M, Franceschi S, Serraino D, Vecchia CL, Talamini

R. Fiber intake and pancreatic cancer risk: a case-control study. Ann Oncol 2012;23(1):264-8.

10. Fang Q, Zhang N, Wu YY, Gan L, Wu BW. Research progress on correlation between dietary and breast cancer prevalence. Chinese Nurs Res 2017;31(34):4326-30

11. McElroy JA, Kruse RL, Guthrie J, Gangnon RE, Robertson JD. Cadmium exposure and endome- trial cancer risk: A large midwestern U.S. population-based case-control study. PLOS ONE 2017;12(7): e0179360

12. Matsuo K, Machida H, Stone RL, Soliman PT, Thaker PH, Roman LD, Wright JD. Risk of subsequent ovarian cancer after ovarian conservation in youngwomen with stage I endometrioid endometrial cancer. Wolters Kluwer Health 2017;130(2):403-11.

13. Plotti F, Capriglione S, Terranova C, Montera R, Scaletta G, Lopez S, Luvero D, Gianina A, Aloisi A, Panici PB. Validation of REM score to predict endometrial cancer in patients with ultrasound endo- metrial abnormalities: results of a new independent dataset. Medical Oncol 2017;34(5):82-6.

14. Yang B. Effect of different dietary models on health. China J Med 2009;9(1):172-4.

15. Ocvirk S, Wilson1 AS, Appolonia1 CN, Thomas TK, O'Keefe SJD. Fiber, Fat, and Colorectal Cancer: New Insight into Modifiable Dietary Risk Factors. Curr Gastroenterol Rep 2019;21(11):62-8.

16. Ma Y, Hu MY, Zhou LN, Ling SK, Li Y, Kong B, Huang PL. Dietary fiber intake and risks of proximal and distal colon cancers. Medicine 2018;97(36):e11678.

17. Oh H, Kim H, Lee DH, Lee A, Giovannucci EL, Kang SS, Keum NN. Different dietary fibre sources and risks of colorectal cancer and adenoma: a dose-response meta-analysis of prospective studies. Br J Nutr2019;122(6):605-15.

18. Masrul M, Nindrea RD. Dietary Fibre Protective against Colorectal
Cancer Patients in Asia: a meta-analysis. OAMJMS 2019;7(10):17237.

19. Gianfredi V, Nucci D, Salvatori T, Dallagiacoma G, Fatigoni C, Moretti M, Realdon S. Rectal cancer: $20 \%$ risk reduction thanks to dietary fibre intake. Systematic Review and Meta-Analysis. Nutrients 2019;11(7):1579.

20. Park SY, Wilkens LR, Kolonel LN, Henderson BE, Marchand LL.Inverse associations of dietary fiber and menopausal hormone therapy with colorectal cancer risk in the multiethnic cohort study. Int $\mathrm{J}$ Cancer 2016;139(6):1241-50.

21. Kraja B, Muka T, Ruiter R, Keyser CD, Hofman A, Franco OH, Stricker BH, Kiefte-de Jong JC. Dietary Fiber Intake Modifies the Positive Association between n-3 PUFA Intake and Colorectal Cancer Risk in a Caucasian Population. J Nutr 2015;145(8):1709-16.

22. Yuan $P$, Li WY, Lin XQ, Yang M, Liu X, Chen ZW, Lin Z, Chen $\mathrm{TH}$, Lin YT, Wang H. Association of dietary fiber intake with colorectal cancer: a matched casecontrol study. Chinese J Public Health, 2016;32(12):1719-23.

23. Ben Q, Sun YW, Chai R, Qian AH, Xu Bin, Yuan YZ. Dietary Fiber Intake Reduces Risk for Colorectal Adenoma: A Meta-analysis. Gastroenterology 2014;146:689-99.

24. Mc Cullough ML, Robertson AS, Chao A, Jacobs EJ, Stampfer MJ, Jacobs DR, Diver WR, Calle EE, Thun MJ. A prospective study of whole grains, fruits, vegetables and colon cancer risk. Cancer Causes Control 2003;14(10):959-70.

25. He XS, Wu K, Zhang XH, Nishihara R, Cao Y, Fuchs CS, Giovannucci EL, OginoSJ, Chan AT, Song MY. Dietary intake of fiber, whole grains and risk of colorectal cancer: an updated analysis according to food sources, tumor location and molecular subtypes in two large US cohorts. Int J Cancer, 2019;145(11):3040-51.

26. Koulouris AI, Luben R, Banim P, Hart AR. Dietary Fiber and the risk of pancreatic cancer. Pancreas 2019;48(1):121-5.

27. Lei QC, Zheng HZ, Bi JC, Wang XY, Jiang TT, Gao XJ, Tian F, Xu $\mathrm{M}$, Wu C, Zhang L, Li N, Li J. Whole grain intake reduces pancreatic cancer risk. Medicine 2016;95(9):e2747.

28. Mao QQ, Lin YW, Chen H, Qin J, Zheng XY, Xu X, Xie LP. Dietary fiber intake is inversely associated with risk of pancreatic cancer: A meta-analysis. Asia Pac J Clin Nutr 2017;26(1):89-96.

29. Bidoli E, Pelucchi C, Zucchetto A, Negri E, Maso LD, Polesel J, Boz G, Montella M, Franceschi S, Serraino D, Vecchia CL, Talamini R.Fiber intake and pancreatic cancer risk: a case-control study. Ann Oncol 2012;23:264-268.

30. June MC, Furong W, Elizabeth AH. Whole grains and risk of pancreatic cancer in a large population-based casecontrol study in the San Francisco bay area, California. Am J Epidemiol2007;166(10):1174-85.

31. Zhang D, Yang L. Dietary Fiber and risk of breast cancer in recent twenty years: a Meta-analysis of prospective studie. Food Nutr China 2017;23(09):62-5.

32. Aune D, Chan DSM, Greenwood DC, Vieira AR, Navarro Rosenblatt DA, Vieira R, Norat T. Dietary fiber and breast cancer risk: a systematic review and meta-analysis of prospective studies. Ann Oncol 2012;23(6):1394-402

33. Liu $\mathrm{ZuW}$, Wang YuM. A Meta analysis of association between 
dietary fiber and carbohydrate intake and risk of breast cancer. Chinese J Health Statistics 2015;32(03):464-70.

34. Farvid MS, Heather Eliassen A, Cho E, Liao XM, Chen WY, Willett WC. Dietary fiber intake in young adults and breast cancer risk. Pediatrics 2016;137(3):e20151226.

35. Liu Y, Colditz GA, Cotterchio M, Boucher BA, Kreiger N. Adolescent dietary fiber, vegetable fat, vegetable protein, and nut intakes and breast cancer risk. Breast Cancer Res Treat 2014;145(2):461-70.

36. Dong JY, He K, Wang PY, Qin LQ. Dietary fiber intake and risk of breast cancer: a meta-analysis of prospective cohort studies. Am J Clin Nutr 2011;94:900-5.

37. Cade JE, Burley VJ, Cade JE, Burley VJ, Greenwood DC. Dietary fibre and risk of breast cancer in the UK Women's Cohort Study. Int. J. Epidemiol 2007;36:431-8.

38. Zhang CX, Zhang CX, Ho SC, Chen YM, Fu JH, Cheng SZ, Lin FY, Suzanne CH. Greater vegetable and fruit intake is associated with a lower risk of breast cancer among Chinese women. Int J Cancer 2009; 125:181-8

39. Park Y, Brinton LA, Subar AF, Hollenbeck A, Schatzkin A. Dietary fiber intake and risk of breast cancer in postmenopausal women: the national institutes of health -AARP diet and health study. Am J Clin Nutr 2009;90:664-71.

40. Mourouti N, Kontogianni MD, Papavagelis C, Psaltopoulou T, Kapetanstrataki MG, Plytzanopoulou P, Vassilakou T, Malamos N, Linos L Panagiotakos DB. Whole grain consumption and breast cancer: a case- control study in women. J Am Coll Nutr 2015;1-7.

41. Newman TM, Vitolins MZ. Cook KL. From the Table to the Tumor: the role of Mediterranean and Western dietary patterns in shifting microbial-mediated signaling to Impact Breast Cancer Risk. Nutrients 2019;11(11):2565

42. Toledo E, Salas-Salvadó J, Donat-Vargas C, Buil-Cosiales P, Estruch R, Ros E, Corella D, Fitó M, Hu FB, Arós F, Gómez-Gracia E, Romaguera D, Ortega-Calvo M, Serra-Majem L, Pintó X, Schröder H, Basora J, Sorlí VJ, Bulló M, Serra-Mir M, Martínez-González MA.Mediterranean diet and invasive breast cancer risk among women at high cardiovascular risk in the PREDIMED trial. JAMA Internal Medicine 2015;175(11):1752-61.

43. Wen W, Shu XO, Li HL, Yang G, Ji BT, Cai H, Gao YT, Zheng W. Dietary carbohydrates, fiber, and breast cancer risk in Chinese women. Am J Clin Nutr 2009;89(1):283-9.

44. Bandera EV, Kushi LK, Moore DF, Gifkins DM, McCullough ML. Association between dietary fiber and endometrial cancer: a doseresponse meta-analysis. Am J Clin Nutr 2007;86(6):1730-7.

45. Chen K, Zhao QY, Li XF, Zhao J, Li PQ, Lin SC, Wang HW, Zang JJ, Xiao J, Xu WH, Chen FX, Gao Y. Dietary fiber intake and endometrial cancer risk: a systematic review and Meta-analysis. Nutrients 2018;10(7):945.

46. Li HJ, Mao H, Yu Y, Nan Y. Association between dietary fiber and endometrial cancer: a meta-analysis. Nutr Cancer 72:6,959-67.

47. Turati F, Galeone C, Gandini S, Augustin LS, Jenkins DJA, Pelucchi C, Vecchia CL. High glycemic index and glycemic load are associated with moderately increased cancer risk. Mol Nutr Food Res 2015;59(7):1384-94.
48. Qiu W, Lu H, Qi Y, Wang XW. Dietary fat intake and ovarian cancer risk: a meta-analysis of epidemiological studies. Oncotarget 2016;7(24):373-90.

49. Hedelin M, Lof M, Andersson TM, Adlercreutz H, Weiderpass E. Dietary phytoestrogens and the risk of ovarian cancer in the women's lifestyle and health cohort study. Cancer Epidemiol Biomarkers Prev 2011;20(2):308-17.

50. Tang L, Lee AH, Su D, Binns CW. Fruit and vegetable consumption associated with reduced risk of epithelial ovarian cancer in southern Chinese women. Gynecologic Oncology 2014;132(1):241-7.

51. Zheng B, Shen H, Han HD, Han T, Qin YH. Dietary fiber intake and reduced risk of ovarian cancer: a meta-analysis. Nutr J 2018;17(1):99108.

52. Xu H, Ding Y, Xin XL, Wang WJ, Zhang DF. Dietary fiber intake is associated with a reduced risk of ovarian cancer_A dose-response meta-analysis. Nutr Res 2018;09(57):1-11.

53. Huang X, Wang XL, Shang J, Lin YZ, Yang Y, Song YY, Yu SN. Association between dietary fiber intake and risk of ovarian cancer: a meta-analysis of observational studies. J Int Med Res 2018;46(10): 3995-4005.

54. Maino Vieytes CA, Mondul AM, Li ZG, Zarins KR, Wolf GT, Rozek LS, Arthur AE. Dietary fiber, whole grains, and head and neck cancer prognosis: findings from a prospective cohort study. Nutrients 2019;11(10):2304.

55. Kawakita D, Kawakita D, Lee YCA, Gren LH, Buys SS, Vecchia CL, Hashibe M. Fiber intake and the risk of head and neck cancer in the prostate, lung, colorectal and ovarian (PLCO) cohort. Int J Cancer 2019;145(9):2342-8

56. Lam TK, Cross AJ, Lam TK, Cross AJ, Freedman N, Park Y, Hollenbeck AR, Schatzkin A, Abnet C. Dietary fiber and grain consumption in relation to head and neck cancer in the NIH-AARP Diet and Health Study.National Institutes of Health 2011;22(10):140514.

57. Bidolia E, Pelucchi C, Polesel J, Negri E, Barzan L, Franchin G, Franceschi S, Serraino D, Paolif PD, Vecchiag CL, Talamini R. Fiber intake and risk of nasopharyngeal carcinoma: a case-control study. Nutr Cancer 2013;65(8):1157-63.

58. Kasum CM, Jacobs DR, Nicodemus K, Folsom AR. Dietary risk factors for upper aerodigestive tract cancers. Int J Cancer 2002; 99(2):267-72.

59. Makarem N, Makarem N, Nicholson JM, Bandera EV, McKeown NM, Parekh N. Consumption of whole grains and cereal fiber in relation to cancer risk: a systematic review of longitudinal studies. Nutr Rev 2016;74(6): 353-73.

60. Liu WS, Zeng YQ, Shao YJ, Wang K. Dietary fiber intake and risk of prostate cancer: a meta-analysis. J Int Oncol 2016;43(10):758-65.

61. Deschasaux M, Pouchieu C, His M, Hercberg S, Latino-Martel $\mathrm{P}$, Touvier M. Dietary total and insoluble fiber intakes are inversely associated with prostate cancer risk. J Nutr 2014;144:504-10.

62. Sawada N, Iwasaki M, Sawada N, Iwasaki M, Yamaji T, Shimazu T, Sasazuki S, Inoue M. Fiber intake and risk of subsequent prostate cancer in Japanese men. Am J Clin Nutr 2015;101(1):118-25.

63. Suzukin R, Allen NE, Key TJ, Appleby PN, Tjønneland A, Johnsen NF, Jensen MK, Overvad K, Boeing H, Pischon T, Kaaks R, Rohrmann 
S, Trichopoulou A, Misirli G, Trichopoulos D, Bueno-de-Mesquita HB, Duijnhoven FV, Sacerdote C, Pala V, Palli D, Tumino R, Ardanaz E, Quiros JR, Larranaga N, Sanchez MJ, Tormo MJ, Jakszyn P, Johansson I, Stattin P, Berglund G, Manjer J, Bingham S, Khaw KT, Egevad L, Ferrari P, Jenab M, Riboli E. A prospective analysis of the association between dietary fiber intake and prostate cancer risk in EPIC. Int J Cancer 2009;124(1):245-9.

64. Wang RJ, Tang JE, Chen Y, Gao JG. Dietary fiber, whole grains, carbohydrate, glycemic index, and glycemic load in relation to risk of prostate cancer. Onco Targets Ther 2015;8:2415-26.

65. Yang W, Ma Y, Liu Y, Smith-Warner SA, Simon TG, Chong DQ, Qi QB, Meyerhardt JA, Giovannucci EL, Chan AT, Zhang XH. Association of intake of whole grains and dietary fiber with risk of hepatocellular carcinoma in US adults. JAMA Oncology 2019;5(6):879-87.

66. FedirkoV, A. Lukanova A, Bamia C, Trichopolou A, Trepo E, Nöthlings U, Schlesinger S, Aleksandrova K, Boffetta P, Tjønneland A, Johnsen NF, Overvad K, Fagherazzi G, Racine A, Boutron-Ruault MC, Grote V, Kaaks R, Boeing H, Naska A, Adarakis G, Valanou E, Palli D, Sieri S, Tumino R, Vineis P, Panico S, Bueno-de-Mesquita HB, Siersema, Peeters, Weiderpass E, Skeie G,Engeset D, Quirós JR, Zamora-Ros R, Sánchez MJ, Amiano P, Huerta JM, Barricarte A, Johansen D, Lindkvist B, Sund M, Werner M, Crowe F, Khaw KT, Ferrari P, Romieu I, Chuang SC, Riboli E, Jenab M. Glycemic index, glycemic load, dietary carbohydrate, and dietary fiber intake and risk of liver and biliary tract cancers in Western Europeans. Ann Oncol 2013;24:543-53

67. Daniel CR, Park Y, Chow WH, Graubard BI, Hollenbeck AR, Sinha R. Intake of fiber and fiber-rich plant foods is associated with a lower risk of renal cell carcinoma in a large US cohort. Am J Clin Nutr 2013;97:1036-43.

68. Yang JJ, Yu DX, Xiang YB, Blot W, White E, Robien K, Sinha R, Park Y, Takata Y, Lazovich DA, Gao YT, Zhang XH, Lan Q, Buenode-Mesquita B, Johansson I, Tumino R, Riboli E, Tjønneland A, Skeie G, Quirós JR, Johansson M, Smith-Warner SA, Zheng W, Shu XO. Association of dietary fiber and yogurt consumption with lung cancer risk. JAMA Oncology 2019;6(2):e194107.

69. Zhang ZZ, Xu G, Ma M, Yang J, Liu X. Dietary fiber intake reduces risk for gastric cancer-A meta-analysis. Gastroenterology 2013; 145(1):113-20.

70. Wu AH, Tseng CC, Hankin J, Bernstein L. Fiber intake and risk of adenocarcinomas of the esophagus and stomach. Cancer Causes Control 2007;18(7):713-22.

71. Sun LL, Zhang ZZ, Xu J, Xu G, Liu XF. Dietary fiber intake reduces risk for Barrett's esophagus and esophageal cancer. Crit Rev Food Sci Nutr 2017;57(13):2749-57.

72. Mulholland HG, Cantwell MM, Anderson LA, Johnston BT, Watson RGP, Murphy SJ, Ferguson HR, McGuigan J, Reynolds JV, Comber H, Murray LJ. Glycemic index, carbohydrate and fiber intakes and risk of reflux esophagitis, Barrett's esophagus, and esophageal adenocarcinoma. Cancer Causes Control 2009;20(3): 279-88.

73. Schatzkin A, Park Y, Leitzmann MF, Hollenbeck AR, Cross AJ. Prospective study of dietary fiber, whole grain foods, and small intestinal cancer. Gastroenterology 2008;135:1163-7.

74. Chiu BCH, Kwon S, Evens AM, Surawicz T, Smith SM,
Weisenburger DD. Dietary intake of fruit and vegetables and risk of non-Hodgkin lymphoma. Cancer Causes Control 2011;22:1183-95.

75. Zhang SM, Hunter DJ, Rosner BA, Giovannucci EL, Colditz GA, Speizer FE, Willett WC. Intakes of fruits, vegetables, and related nutrients and the risk of Non-Hodgkin's lymphoma among women. Cancer Epidemiol Biomarkers Prev 2000;9:477-85.

76. Alberts DS, Martinez ME, Roe DJ, Guillen-rodriguez JM, Marshall JR, Van Leeuwen JB, Reid M, Ritenbaugh C, Vargas PA, Bhattacharyya $A B$, Earnest DL, Sampliner RE. Lack of effect of a high-fiber cereal supplement on the recurrence of colorectal adenomas. N Engl J Med 2000;342:1156-62.

77. Jacobs ET, Giuliano AR, Roe DJ, Guille'n-Rodr'guez JM, Alberts DS, Martı'nez ME. Baseline dietary fiber intake and colorectal adenoma recurrence in the wheat bran fiber randomized trial. J Natl Cancer Inst 2002;94(21):1620-5.

78. Nakaji S, Shimoyama T, Wada S, Sugawara K, Tokunaga S, MacAuley D, Baxter D. No preventive effect of dietary fiber against colon cancer in the Japanese population: a cross-sectional analysis. Nutr Cancer 2009;45(2):156-9.

79. Skeie G, Braaten T, Olsen A, Kyrø C, Tjønneland A, Nilsson LM, Landberg R, Lund E. Whole Grain Intake and Survival Among Scandinavian Colorectal Cancer Patients. Nutr Cancer 2015;66(1):613.

80. Sansbury L, Wanke K, Sansbury LB, Wanke K, Albert PS, Kahle L, Schatzkin A, Lanza E. The Effect of strict adherence to a highfiber, high-fruit and -vegetable, and low- fat eating pattern on adenoma recurrence.Am J Epidemiol 2009;170:576-84.

81. Sivaprakasam S, Bhutia YD, Yang S; Ganapathy V. Short-chain fatty acid transporters: role in colonic homeostasis. Compr Physiol 2018;8(1):299-314.

82. Jacobs ET, Lanza E, Alberts DS,Hsu CH, Jiang R, Schatzkin A, Thompson PA, Martínez ME. Fiber, sex, and colorectal adenoma: results of a pooled analysis. Am J Clin Nutr 2006;83(2):343-9.

83. Yao Y, Suo T, Ander sson R, Cao Y, Wang C, Lu J, Chui E. Dietary fibre for the prevention of recurrent colorectal adenomas and carcnoma (Review). Cochrane Database Syst Rev. 2017;1(1):CD003430.

84. Xu M, Zhang CX. A ssociation between dietary fiber intake and cancer risk and prognosis. Electron J Metab Nutr Cancer 2015;2(03): 42-8.

85. Pierce JP, Natarajan L, Caan BJ, Parker BA, Greenberg ER, Flatt SW, Rock CL, Kealey S, Al-Delaimy WK, Bardwell WA, Carlson RW, Emond JA, Faerber S, Gold EB, Hajek RA, Hollenbach K, Jones LA, Karanja N, Madlensky L, Marshall J, Newman VA, Ritenbaugh C, Thomson CA, Wasserman L, Stefanick ML. Influence of a diet very high in vegetables, fruit, and fiber and low in fat on prognosis following treatment for breast cancer: the Women's Healthy Eating and Living (WHEL) randomized trial. JAMA 2007;298(3):289-98.

86. Henson CC, Burden S, Davidson SE, Lal S. Nutritional interventions for reducing gastrointestinal toxicity in adults undergoing radical pelvic radiotherapy (Review). Cochrane Database Syst Rev 2013;11:CD009896.

87. Feng XH, Ge S. Sugar, dietary fiber and tumors.Electron J Metab Nutr Cancer 2014;1(3):31-4

88. Wang Y. Effects of dietary fiber on nutritional status and immune 
function in patients with pelvic radiotherapy [D]. Shandong: Shandong University 2019;62.

89. Song M, Chan AT. Environmental factors, gut microbiota, and colorectal cancer prevention. Clin Gastroenterol Hepatol 2019;17(2): 275-89.

90. Prado SB, Castro-Alves VC, Ferreira GF, Fabi JP. Ingestion of non-digestible carbohydrates from plant-source foods and decreased risk of colorectal cancer: a review on the biological effects and the mechanisms of action. Front Nutr 2019;6:72.

91. Ohtani N, Yoshimoto S, Hara E. Obesity and cancer: a gut microbial connection. Cancer Res 2014;74(7):1885-89.

92. Gallagher EJ, LeRoith D. Obesity and Diabetes: the increased risk of cancer and cancer-related mortality. Physiol. Rev 2015;95(3):72748 .

93. Moghaddam AA, Woodward M, Huxley R. Obesity and risk of colorectal cancer: a Meta-analysis of 31 studies with 70,000 events. Cancer Epidemiol Biomarkers Prev 2007;16(12):2533-47.

94. Yang Y, Tao T, Ji N, Wang YJ. Function of dietary fiber in prevention and treatment of colon carcinoma. Medical Recapitulat 2010;16(10):1494-6. 